\title{
DIALETIKA ETNOGRAFI KOMUNIKASI EMIK-ETIK PADA KAIN TENUN
}

\author{
Emanuel S. Leuape ${ }^{1}$ dan Susanne Dida ${ }^{2}$ \\ ${ }^{1}$ Universitas Nusa Cendana Kupang \\ ${ }^{2}$ Universitas Padjadjaran
}

\begin{abstract}
ABSTRAK
Penelitian ini bertujuan mendialetikakan pemaknaan emik-etik simbol warna dan gambar kain tenun (Mollo) desa Tutem. Tahapan pada penelitian ini yaitu interpretasi (Ferdinand De Saussure), reinterpretasi (Roland Barthes), Dialog (Jurgen Habermas), dan dekonstruksi (Jaques Derrida). Hasil interpretasi (emik) dan reinterpretasi (etik), didialetikakan dengan menghasilkan sintesis berupa dialog antara masyarakat Tutem dan peneliti, diakhiri dengan analisis dekonstruksi guna mengantisipasi potensi kemajemukan makna simbol warna dan gambar kain tenun desa Tutem di kemudian hari. Paradigma penelitiannya adalah kualitatif dan bermetode studi etnografi komunikasi. Data diperoleh dengan wawancara mendalam, observasi-partisipatoris, dan dokumentasi visual kain tenun. Hasil penelitian ini adalah: dalam pemaknaan emik masyarakat Tutem, simbol warna kain tenun mengacu pada keberagaman kelompok suku dan simbol gambar kain tenun merujuk kepada realitas historis. Pemaknaan etik peneliti, simbol warna dan gambar kain tenun merujuk kepada kondisi geografis (Sumber Daya Alam), moral dan perilaku sosial (Sumber Daya Manusia), dan sejarah. Melalui prosedur tindakan komunikatif (dialog), kesepakatan intersubjektif yang dicapai, mencakup: 10 jenis simbol warna dan 7 varian gambar kain tenun diterima dan 2 varian gambar kain tenun ditolak. Terdapat 3 jenis simbol warna dan pola gambar ruang kain tenun yang wajib didekonstruksi maknanya oleh peneliti. Proses interpretasi, reinterpretasi, dialog, dan dekonstruksi menjadi tahapan ideal dalam memberdayakan kain tenun sebagai salah satu wujud produk kebudayaan masyarakat Tutem. Pelaksanaan tahapan tersebut melibatkan peran aktif masyarakat Tutem dan peneliti. Akhirnya, masyarakat Tutem dan peneliti sama-sama membangun 'cerita' tentang simbol warna dan gambar kain tenun dalam spirit falibilisme.
\end{abstract}

Kata-kata Kunci: Kain tenun, komunikasi, warna-gambar, emik-etik, dialetika

\section{COMMUNICATION ETHNOGRAPHY EMIC-ETHICS DIALETICAL IN WOVEN CLOTH}

\section{ABSTRACT}

This research was used dialectics in analyzing emic-ethics meaning of the symbol colors and images in woven cloth (Mollo) of community Tutem. Stages of this study were divided into, the interpretation (Ferdinand de Saussure), reinterpretation (Roland Barthes), Dialog (Jurgen Habermas), and deconstruction (Jacques Derrida). The result of interpretation (emic) and reinterpretation (ethics), will be used dialectics in analyzing to produce synthetic form of dialogue between Tutem's and researchers. It will be end with deconstruction analysis to anticipate the plurality meanings of color and image symbols of woven cloth. Approach that is used is qualitative to the study ethnography communication symbols. Data obtained by conducting in-depth interviews, observation-participatory, and visual documentation. The results showed that: In the emical interpretation of Tutem, color symbols refers to the diversity of sub-ethnic groups and image symbols refers to a historical reality. Ethical reinterpretation, the symbols of colors and images refers to the geographical conditions (Natural Resources), morality and social behavior (Human Resources), and history. Through communicative action (dialogue), intersubjective agreement is reached, that is: 10 kinds of colors and 7 variants of images was ejected and 2 variants of picture was rejected. There are 3 kinds of colors and patterns images that must be deconstructed meaning. The process of interpretation, reinterpretation, dialogue and deconstruction become an ideal intellectual working to useful woven cloth as one form of cultural product of community Tutem. Implementation of these intellectual working involve community Tutem and researchers leading role. Finally, the community Tutem and researchers alike build a 'story' about the color and image symbols of woven cloth in Fallibilism spirit.

Keywords: Woven cloth, communication, color-image, emic-ethics, dialectics

Korespondensi: Emanuel S Leuape, M.I.Kom. Universitas Nusa Cendana Kupang, Jln. San Juan, RT. 012/ RW.006, Kel. Sarotari, Kec. Larantuka, Kab. Flores Timur, Prov. Nusa Tenggara Timur (NTT). Email: blondaeman28@gmail.com 


\section{PENDAHULUAN}

Manusia dan kebudayaan memiliki hubungan dialektis. Maksud penciptaan kebudayaan oleh manusia adalah sebagai landasan atau pedoman hidup manusia. Kebudayaan ada karena manusia menciptakannya dan manusia dikondisikan hidup di tengah-tengah kebudayaan yang diciptakannya. Van Peursen menyatakan kebudayaan merupakan endapan dari kegiatan dan karya manusia. Sebagai "endapan" kegiatan dan hasil karya manusia, tentunya kebudayaan paling tidak juga turut merepresentasikan manusia sebagai penciptanya (Peursen, 2005: $10)$.

Salah satu produk kebudayaan yang dimaksudkan yakni kain tenun. Penelitian ini bergerak dari asumsi eksistensi tenun lebih dari sekadar fungsinya sebagai busana semata, yakni sebagai representasi makna simbolis. Tenun merupakan ekspresi kebudayaan dalam fungsi simbolisnya, termasuk tampilan visualnya. Tenun sebagai busana justru dapat dimetaforakan sebagai 'kulit sosial dan budaya manusianya'. Asumsi ini paling tidak sejalan dengan pemahaman Umberto Eco bahwa tenun sebagai pakaian tubuh merupakan alat semiotika dan mesin komunikasi (Barnard, 2007: i). Oleh karena itu, penelitian ini akan fokus pada produk kain tenun (Mollo) masyarakat Tutem, Kecamatan Tobu, Kabupaten Timor Tengah Selatan (TTS), Provinsi Nusa Tenggara Timur (NTT).

Secara umum, corak pada tenunan masyarakat Tutem mengikuti karakteristik kebudayaan daerah adat (Sonaf) Mollo yang mana merupakan salah satu sonaf dari 3 sonaf yang berada di kabupaten TTS. Kabupaten TTS terdiri dari 3 sonaf, yakni Mollo (Oenam), Amanuban (Banam), dan Amanatun (Onam). Tampilan visual kain tenun sonaf Mollo lebih mencolok karena didominasi oleh kombinasi warna yang cerah seperti merah, kuning, hijau, biru, orange, dan sebagainya, serta kaya akan kombinasi gambar terutama gambar geometris dan fauna. Hal ini tentunya berbeda dari tenunan 2 sonaf lainnya yang didominasi oleh warna gelap. Tampilan visual yang mencolok pada tenunan daerah Mollo inilah yang menarik perhatian peneliti untuk selanjutnya mencoba meneliti hasil tenunan Mollo, khususnya di desa Tutem ini.
Di sini, peneliti bermaksud meneliti makna tampilan visual warna dan gambar pada tenunan Mollo hasil karya masyarakat Desa Tutem. Melalui simbol warna dan gambarnya, kain tenun juga merepresentasikan realitas kehidupan sosio-kultural pemakainya. Realitas kehidupan yang dimaksud mencakup: kondisi geografis (Sumber Daya Alam), moral dan perilaku sosial (Sumber Daya Manusia), dan historis. Dalam pra-observasi, peneliti menemukan bahwa masyarakat desa Tutem telah memiliki pemaknaan tersendiri terhadap simbol warna dan gambar pada kain tenunnya yang merujuk kepada tiga poin realitas sebagaimana yang dipaparkan sebelumnya. Namun, yang menjadi masalah bagi peneliti bahwasannya pemaknaan khas masyarakat Tutem tersebut masih relatif 'sederhana'. Dalam perspektif peneliti, kekompleksan ragam simbol warna dan gambar kain tenun seharusnya berbanding lurus dengan kekompleksan eksistensi realitas sosiol-kultural masyarakat pemakainya.

Oleh karena itu, via penelitian ini peneliti merasa tertarik untuk menghadirkan satu bentuk pemaknaan simbolis terhadap ragam warna dan gambar kain tenun kelompok masyarakat Tutem secara lebih 'kompleks'. Oleh karena itu, peneliti menggunakan metode etnografi komunikasi simbol untuk memaparkan unsur-unsur ekspresif (dalam ragam jenis warna dan bentuk gambar) kain tenun dan prosedur pengacuan makna-maknanya. Upaya optimalisasi makna simbol warna dan gambar kain tenun ini, akan dilakukan ditempuh dengan 4 tahapan kerja penelitian, yaitu: Interpretasi (Semiotika Ferdinand De Saussure), Reinterpretasi (Roland Barthes), Dialog (Jurgen Habermas), dan Dekonstruksi (Jaques Derida). Interpretasi natif kelompok masyarakat Tutem selanjutnya akan didialetikakan dengan reinterpretasi peneliti.

Kompilasi kedua bentuk pemaknaan kain tenun demikian, akan menghasilkan satu sintesis, yaitu dialog. Melalui dialog, hasil reinterpretasi peneliti akan didiskusikan bersama dengan masyarakat Tutem guna memperoleh kesepakatan intersubjektif. Konsekuensinya, hasil pemaknaan peneliti bisa saja diterima atau ditolak oleh mereka. Terutama hasil reinterpretasi yang diterima tentunya akan menambah kekayaan pemaknaan simbolis warna dan gambar kain tenun masyarakat Tutem sendiri. Kerangka kerja penelitian etnografi komunikasi simbol ini akan diakhiri 
dengan semangat dekonstruksi. Dekonstruksi dimaksudkan sebagai sikap ilmiah dalam rangka upaya mengakomodir adanya transformasi pemaknaan simbolis tampilan visual kain tenun ke depannya. Meskipun informan native dan peneliti telah sampai pada titik konsensus terkait pemaknaan simbolis yang legitim kini, tetapi hal itu tidaklah menjadi satu kebenaran tunggal yang permanen dan abadi. Dalam periode waktu ke waktu, ada momen-momen lain di mana ada pemaknaan lain atas tampilan visual kain tenun oleh berbagai penelitian sejenis selanjutnya. Dekonstruksi menjadi poin sikap ilmiah yang dipilih oleh peneliti dalam penelitian ini sebagai bentuk apresiasi atas kemajemukan pemaknaan terhadap entitas-entitas realitas kehidupan manusia.

Bagi peneliti, penelitian ini sebagai penelitian akademik ilmiah yang mencoba mengkombinasikan berbagai perspektif teoritis dalam satu kerangka pemikiran atau kerja penelitian yang bertahap dalam meninjau satu realitas komunikasi manusia dan (atau) membentuknya secara lebih kaya. Kebanyakan penelitian yang sudah dilakukan hanya berangkat dari satu perspektif atau membedah realitas menurut tiap perspektif secara diferensiatif tanpa mencoba mengformulasikan berbagai perspektif teoritis tersebut dalam satu kerangka pemikiran atau kerja penelitian yang saling terkait.

Banyak peneliti mungkin berpikir bahwa melakukan penelitian dengan banyak perspektif teoritis akan mengakibatkan ambiguitas orientasi penelitian dan karenanya, mereka cenderung hanya berangkat dari satu perspektif teoritis. Akan tetapi, penelitian lintas perspektif yang kombinatif ini dapat menjadi penelitian empirik yang dapat diacu atau dirujuk oleh penelitian selanjutnya baik dalam tema atau perspektif yang sama maupun berbeda. Penelitian ini menjadi wujud bukti yang berkontribusi bagi penelitian akademik ilmiah bahwa penelitian lintas perspektif teori dapat dilakukan jika diformulasikan secara logis dan sistematis.

Tiap manusia perlu membangun hubungan sosial dengan sesamanya dan kebutuhan ini terpenuhi melalui momen interaksi. Dunia interaksi antar manusia terjalin melalui proses komunikasi. Komunikasi manusia tidak hanya terbatas pada bahasa tulisan atau lisan, melainkan mencakup juga perilaku atau objek yang mewakili makna tertentu (Liliweri,
2002: 5). Hal ini tercermin pada eksistensi simbolis kain tenun sebagai objek penelitian ini. Kain tenun dan simbol warna-gambarnya merupakan kode-kode bahasa non-verbal yang turut difungsikan dalam transaksi makna antar individu atau kelompok manusia. Jadi, fenomena komunikasi itu berkarakter serba ada, serba luas, dan serba makna (West dan Turner, 2008: 5).

Corak komunikasi penelitian ini dilandasi oleh 2 hal, yaitu: 1) penelitian ini melakukan proses pemaknaan (meaning) pada simbol warna dan gambar kain tenun sebagai objek komunikasi yang mengandung makna tertentu. 2) salah satu tahapan kerja penelitian ini menyelenggarakan prosedur tindakan komunikatif, yaitu dialog. Dialog mengkondisikan 2 pihak saling berinteraksi. Dalam interaksi tersebut, terdapat kontak dan proses komunikasi yang diselenggarakan dalam mencapai kesepakatan intersubjektif. Kain tenun merupakan produk budayayang berkaitan erat dengan komunikasi.

Alo Liliweri berpendapat kebudayaan adalah komunikasi simbolisme. Simbolisme itu adalah keterampilan kelompok dan produknya, pengetahuan, sikap, nilai, dan motif (2009: 8-9). Dimensi warna dan gambarkain tenun masyarakat Tutem merupakan potretkomunikasi simbol yang menandai makna tertentu. Hal ini sejalan dengan pandangan Umberto Eco bahwa fenomena kebudayaan sebagai fenomena tanda yang bermakna. Kebudayaan perlu dipahami secara semiotik, yakni jejaring makna (webs of signifance atau fabric of meaning) atau polapola makna yang terwujud sebagai simbolsimbol sehingga analisis terhadap kebudayaan itu sendiri mestilah bersifat interpretatif (Budiman, 2004: 21).

Eksistensi warna dan gambar kain tenun dimaksudkan sebagai media ekspresi makna. Merujuk pada pendapat James P. Spradley, makna menyampaikan pengalaman sebagian besar umat manusia di dalam masyarakat (Sobur, 2009: 25). Asumsi bahwa corak warna dan gambar kain tenun berdimensi simbolis menegaskan pendapat Alo Liliweri bahwa makna sebenarnya mencakup pikiran, perasaan, ide maupun gagasan yang dimaksudkan yang terkandung dalam pesan verbal maupun nonverbal (2002: 6).

Dengan menggunakan simbol warna dan gambar kain tenun sebagai media ekspresi 
makna, maka masyarakat Tutem dapat dikatakan sebagai animal simbolicum, yaitu manusia berpikir, berperasaan, dan bersikap dengan ungkapan-ungkapan simbolis (Sobur, 2009: 14). Demikian pun, semua makna budaya diciptakan dan diekspresikan melalui simbol-simbol. Fungsi simbolisme kain tenun merupakan proses-proses visualisasi yang cenderung ditemukan dalam kebudayaan Timur (Mulyana dan Rakhmat, 2009: 54). Masyarakat Tutem merupakan ras Melanesia Timur yang menggunakan busana tradisional sebagai media komunikasi budaya kelompoknya.

Corak warna dan gambar pada kain tenun masyarakat Tutem memiliki 2 fungsi, yaitu sebagai konstruksi seni (keindahan) sekaligus kode bahasa komunikasi. Kedua aspek ini berada pada satu objek material kain tenun yang punya bisa ditilik dari dimensi cara pandang kesenian dan komunikasi. Produk budaya material berupa kain tenun bisa dipandang sebagai teks jikalau diposisikan sebagai objek penelitian etnografi komunikasi (simbol). Terdapat 3 poin etnografi komunikasi yang dipakai guna mengkaji eksistensi simbolis kain tenun, yaitu: 1) Bentuk (varietas pesan), 2) Isi pesan yang mencakup apa yang dikomunikasikan, termasuk level konotatif dan refrensi denotatif, dan 3) Pedoman interpretasi, di antaranya: pengetahuan umum (common sense), nilai (value), dan kebiasaan (habits) (Kuswarno, 2008: 11).

Hasil etnografi komunikasi simbolis kain tenun dipetakan ke dalam hasil pemaknaan emik (native), yaitu makna interpretasi masyarakat Tutem terhadap simbol warna dan gambar kain tenunnya sendiri dan hasil pemaknaan etik, yakni hasil makna reinterpertasi peneliti terhadap simbol warna dan gambar kain tenun masyarakat Tutem. Kedua bentuk makna tersebut akan di-dialetika-kan guna melengkapi kecacatan masing-masingnya. Prosedural dialetika dapat dirumuskan dalam 3 tahap. Tahap pertama adalah sebuah tesis yang lalu memunculkan tahap kedua, antitesis. Akhirnya, keduanya diperdamaikan dalam sebuah sintesis (Hardiman, 2004: 181). Urgensi proses dialetika ini mencerminkan apresiasi kerja intelektual terhadap praksis kerjanya sekaligus praksis komunikasinya (Magni-Suseno, 2005: 164).

Secara garis besarnya, proses dialetika penelitian ini ditandai oleh 4 tahapan kerangka pemikiran atau kerja penelitian ini. Tahapan awal dimulai oleh proses interpretasi dalam kacamata semiotika Ferdinand de Saussure. Saussure mengasumsikan tanda terdiri atas 2 bagian yaitu penanda (signifier) dan petanda (signified). Penanda dan petanda akan dihubungkan oleh pemaknanya (manusia). Keseluruhan proses ini dinamakan signification (Sobur, 2009: 46). Perspektif ini dipakai dalam mengidentifikasi makna emik simbol warna dan gambar kain tenun masyarakat Tutem.

Tahapan reinterpretasi akan menggunakan semiotika Roland Barthes. Barthes menekankan makna konotasi, yaitu makna hasil kreativitas penafsir dalam memaknai tanda-tanda (Pawito, 2007: 53). Dengan konsepsi makna konotasi, Barthes menekankan bahwa penanda tidak bisa dibakukan pada satu petandanya, melainkan selalu berpotensi untuk mengacu pada pluralitas petanda tergantung kreativitas pemaknanya. Sehingga Barthes menghendaki 'kematian otoritas pengarang' dan menghendaki 'kehadiran otoritas pembaca'. Bagi Barthes tanda harus bersifat readerly, yakni terbuka pada berbagai bentuk tafsiran atau fleksibel dalam pemaknaannya (Sutrisno dan Putranto, 2009: 115). Sudut pandang ini akan difungsikan dalam mereinterpretasikan makna simbol warna dan gambar kain tenun masyarakat Tutem.

Dialog menjadi jalan ideal yang diupayakan Jurgen Habermas dalam konsepsi Tindakan Komunikatif. Tiap ide, gagasan, atau makna yang bertujuan untuk dijadikan pengetahuan dan landasan tindakan sosial, maka harus terlebih dahulu disepakati dalam diskusi bersama. Momen komunikasi itu harus berlangsung secara egaliter, bebas, rasional, dan terbuka (Hardiman, 2009: 24). Tindakan komunikatif ini dimaksudkan mendiskusikan hasil pemaknaan etik peneliti guna memperoleh persetujuan ataupun penolakan.

Bentuk-bentuk pemaknaan yang telah disepakati bersama tidak menutup potensi pluralitas makna di kemudian hari. Oleh karena itu, Jaques Derrida melalui rumusan dekonstruksi mencoba mengantisipasi potensi kemajemukan makna tersebut. Dekonstruksi dilandasi asumsi bahwa eksistensi tanda merupakan kreativitas imajinasi manusia dan signifikasi tanda diproduksi oleh konsensus sosial. Sebagai hasil kerja imajinasi manusia maka tanda tidak bersifat alami dan abadi. Sebagai hasil konsensus sosial, maka relasi penanda dan petanda selalu berpotensi untuk terus direkonstruksi (Al-Fayyadl, 2006: 153) 


\section{METODE PENELITIAN}

Penelitian ini diposisikan sebagai paradigma penelitian kualitatif. Deddy Mulyana dan Solatun mendefinisikan penelitian kualitatif sebagai penelitian yang bersifat interpretatif (menggunakan penafsiran) yang melibatkan banyak metode, dalam menelaah masalah penelitiannya (Mulyana dan Solatun, 2007: 5). Penelitian kualitatif digunakan ketika masalah yang luas dan kompleks perlu dieksplorasi untuk memperoleh pemahaman yang lebih mendalam dan spesisifik. Kualitas penelitian kualitatif sangat tergantung pada kemampuan peneliti dalam mengidentifikasi, memetakan, menganalisis, dan mendeskripsikan objek penelitiannya. Hal ini juga dapat ditindaklanjuti dengan menarik beberapa kesimpulan konseptual atau teoritis dari pemaknaan objek yang dikaji (analisis induksi).

Penelitian ini tentunya merupakan wujud penelitian kualitatif karena menggunakan mekanisme analisis interpretasi, terutama nampak dalam interpretasi semiotika Saussure dan reinterpretasi Barthes. Diskursus Habermas dan dekonstruksi Derrida juga menandai paradigma berpikir kualitatif karena membingkai objek penelitiannya dalam bentuk pemaknaan yang mendalam, spesifik, relatif, dan kontekstual.

Penelitian ini menggunakan metode etnografi yang fokus pada produksi simbolsimbol komunikasi dari satu kelompok budaya. Sehingga penelitian ini ditematisasi menjadi etnografi komunikasi simbol. Secara historis, penelitian etnografi dikembangkan dalam rangka memahami pandangan dunia dan cara hidup satu kelompok budaya dalam konteks pengalaman keseharian hidupnya. Penelitian ini membedakan 2 peran etnografi yang digunakannya, yaitu: etnografi sebagai metode penelitian dan sebagai cara penulisan (Kruger, 2008: 41). Dalam penelitian ini, laporan etnografi hadir dalam bentuk analisis emik sekaligus etik. Selanjutnya, keduanya didialetikan sebagai upaya memediasi tegangan perbedaan di antaranya melalui tindakan komunikatif dan diakhiri dengan apresiasi atas potensi pluralitas dalam analisis pemaknaan.

Pengumpulan data dilakukan melalui tiga teknik, yaitu: wawancara mendalam (indept interview), observasi-partisipatoris (observation-participation), dan dokumentasi visual. Sedangkan validasi data akan dilakukan melalui metode triangulasi data, yaitu melihat similaritas berbagai data yang diperoleh dari metode pengumpulan yang berbeda.

\section{HASIL DAN PEMBAHASAN}

Hasil penelitian etnografi komunikasi simbol ini akan dipetakan ke dalam 4 tahapan kerangka pemikiran atau kerjanya, yaitu interpretasi, reinterpretasi, dialog, dan dekonstruksi. Terdapat 10 corak warna pada kain tenun masyarakat Tutem, yaitu: merah, hijau, kuning, hitam, putih, merah muda, biru muda, orange, ungu, dan kuning emas. Sedangkan simbol gambar pada kain tenun masyarakat Tutem teridentifikasi ke dalam 9 bentuk gambar, yaitu: 1 gambar utama Ausnobif dan 1 varian, 1 gambar utama Lulkolo dan 4 variannya, 1 gambar Mauninef orang, 1 gambar Mauninef burung, dan 1 gambar Abata.

Pada pemaknaan emik masyarakat Tutem sendiri, ragam simbol warna yang dikenakan pada kain tenunnya mengacu pada keragaman kelompok sub-budaya (suku) yang hidup dalam lingkup sosialnya. Masyarakat Tutem awalnya terdiri atas 4 suku utama, yakni: Tafui, Sunbanu, Seko, dan Baun. Keempat suku ini dikenal dengan sebutan kaum Atoinamaf dengan status dan peranannya masing-masing. Suku Tafui dan Sunbanu merupakan dua suku yang berstatus sebagai pemimpin dan tentara perang (atitapa atau abiupah). Sedangkan suku Seko dan Baun memiliki peran sebagai penjaga kampung (Soemutu) ketika kedua suku lainnya berpergian untuk berperang di wilayah lain.

Dari keempat suku Atoinamaf inilah lahir suku-suku asli lainnya di desa Tutem, di antaranya: suku Oematan, Haekase, Tapatab, Fallo, Leob, Babu, Nomeni, Mnune, Kune, Funome, Hana, Konay, Lake, Lasfeto, Hune, Takesan, Kase, Aplugi, Loasana, dan Nale. Masing-masing suku ini tersebar di 3 wilayah yaitu: wilayah desa Bijaipunu, wilayah desa Tutem, dan wilayah desa Tobu. Ketiga wilayah ini merupakan satu wilayah kefektoran yang dinamakan kefektoran Paenenotobu. Sedangkan dalam pemaknaan emik simbol gambar pada kain tenun, mencakup: gambar utama Ausnobif dan variannya merepresentasikan realitas historis keberadaan hewan karnivora anjing yang konon membantu leluhur masyarakat Tutem menemukan tempat tujuan akhirnya 
(wilayah desa Tutem), gambar utama Lulkolo dan variannya mengacu pada mitos sejarah keberadaan hewan karnivora elang yang pernah menjadi alat transportasi bagi bala tentara perang masyarakat Tutem, gambar Mauninef orang melambangkan realitas keragaman kelompok suku masyarakat Tutem, gambar Mauninef burung mengacu pada mitos sejarah hewan karnivora elang, dan gambar Abata merepresentasikan pluralitas kelompok suku masyarakat Tutem.
Dalam interpretasi makna emik demikian, peneliti hanya mengidentifikasi penanda (warna dan gambar) dan petanda (makna emiknya), serta proses signifikasinya. Hasil reinterpretasi makna etik dari peneliti mencoba memperkaya acuan makna simbol warna dan gambar pada kain tenun masyarakat Tutem. Dengan menggunakan mekanisme produksi tanda konotasi dalam konsepsi Barthes, maka pemaknaan etiknya, peneliti rangkum dalam tabel 1 .

\section{Tabel 1 Hasil Pemaknaan Etik Simbol Warna Kain Tenun}

\begin{tabular}{|c|c|c|c|c|c|}
\hline No & Jenis Warna & Emik & Etik Objektif & Etik Subjektif & Rujukan Realitas \\
\hline 1 & Merah $($ Red $)$ & $\begin{array}{l}\text { Eksistensi } \\
\text { keragaman } \\
\text { sub } \\
\text { kelompok } \\
\text { budaya } \\
\text { (Suku) }\end{array}$ & $\begin{array}{l}\text { Jenis warna primer } \\
\text { dalam kelompok } \\
\text { warna dasar RGB } \\
\text { (Red-Green-Blue) }\end{array}$ & Keberanian & $\begin{array}{l}\text { Kisah sejarah } \\
\text { keberanian tokoh dan } \\
\text { bala tentara perang } \\
\text { masyarakat Tutem. }\end{array}$ \\
\hline 2 & $\begin{array}{l}\text { Hijau } \\
\text { (Green) }\end{array}$ & Idem & $\begin{array}{l}\text { Jenis warna primer } \\
\text { dalam kelompok } \\
\text { warna dasar RGB } \\
\text { (Red-Green-Blue) }\end{array}$ & $\begin{array}{l}\text { Kesuburan dan } \\
\text { kekayaan hasil } \\
\text { alam }\end{array}$ & $\begin{array}{l}\text { Kondisi alam desa } \\
\text { Tutem yang subur dan } \\
\text { kaya hasil alam. }\end{array}$ \\
\hline 3 & $\begin{array}{l}\text { Kuning } \\
\text { (Yellow) }\end{array}$ & Idem & $\begin{array}{l}\text { Jenis warna primer } \\
\text { dalam kelompok } \\
\text { warna CYM } \\
\text { (Cyan-Yellow- } \\
\text { Magenta) }\end{array}$ & $\begin{array}{l}\text { Keterbukaan } \\
\text { dan } \\
\text { kehangatan }\end{array}$ & $\begin{array}{l}\text { Kehidupan sosial } \\
\text { masyarakat Tutem } \\
\text { yang relatif } \\
\text { bersikapterbuka } \\
\text { dan membangun } \\
\text { kebersamaan dengan } \\
\text { orang lain. }\end{array}$ \\
\hline 4 & $\begin{array}{l}\text { Hitam } \\
(\text { Black })\end{array}$ & Idem & $\begin{array}{l}\text { Campuran tiga } \\
\text { jenis warna primer } \\
\text { CYM }(1: 1: 1)\end{array}$ & Kemisteriusan & $\begin{array}{l}\text { Kehidupan sosial- } \\
\text { budaya masyarakat } \\
\text { Tutem yang masih } \\
\text { mempertahankan } \\
\text { sisi mistis pada } \\
\text { bentuk kepercayaan } \\
\text { tradisionalnya. }\end{array}$ \\
\hline 5 & Putih (White) & Idem & $\begin{array}{l}\text { Campuran tiga } \\
\text { jenis warna primer } \\
\text { RGB }(1: 1: 1)\end{array}$ & $\begin{array}{l}\text { Kepolosan dan } \\
\text { kesederhanaan }\end{array}$ & $\begin{array}{l}\text { Kehidupan sosial } \\
\text { masyarakat Tutem } \\
\text { yang tampil natural } \\
\text { dan sederhana sebagai } \\
\text { identitasnya. }\end{array}$ \\
\hline 6 & $\begin{array}{l}\text { Warna } \\
\text { Merah Muda } \\
(\text { Pink })\end{array}$ & Idem & $\begin{array}{l}\text { Jenis warna tersier } \\
\text { dari campuran } \\
\text { warna Merah+Putih } \\
(1: 1 / 2)\end{array}$ & $\begin{array}{l}\text { Feminitas; } \\
\text { Jiwa sosial } \\
\text { tinggi }\end{array}$ & $\begin{array}{l}\text { Kehidupan sosial } \\
\text { masyarakat Tutem yang } \\
\text { menjunjung tinggi } \\
\text { kepekaan sosial tinggi } \\
\text { dalam komunikasi dan } \\
\text { interaksinya dengan } \\
\text { orang lain. }\end{array}$ \\
\hline
\end{tabular}




\begin{tabular}{|c|c|c|c|c|c|}
\hline No & Jenis Warna & Emik & Etik Objektif & Etik Subjektif & Rujukan Realitas \\
\hline 7 & $\begin{array}{l}\text { Warna Biru } \\
\text { Muda (Cyan) }\end{array}$ & Idem & $\begin{array}{l}\text { Jenis warna } \\
\text { tersier dari } \\
\text { campuran warna } \\
\text { Biru+Putih }(1: 1 / 2)\end{array}$ & Kepercayaan & $\begin{array}{l}\text { Kehidupan sosial masyarakat } \\
\text { Tutem yang menyanjung nilai } \\
\text { kepercayaan dalam interaksi dan } \\
\text { komunikasi dengan orang lain. }\end{array}$ \\
\hline 8 & $\begin{array}{l}\text { Orange } \\
\text { (Orange) }\end{array}$ & Idem & $\begin{array}{l}\text { Jenis warna } \\
\text { sekunder dari } \\
\text { campuran warna } \\
\text { Merah+Kuning } \\
(1: 1)\end{array}$ & Fleksibelitas & $\begin{array}{l}\text { Kehidupan sosial masyarakat } \\
\text { Tutem yang welcome terhadap } \\
\text { berbagai bentuk perubahan } \\
\text { yang dipercaya baik bagi } \\
\text { kelangsungan hidupnya. }\end{array}$ \\
\hline 9 & $\begin{array}{l}\text { Ungu } \\
\text { (Magenta) }\end{array}$ & Idem & $\begin{array}{l}\text { Jenis warna } \\
\text { primer dalam } \\
\text { kelompok warna } \\
\text { dasar CYM } \\
\text { (Cyan-Yellow- } \\
\text { Magenta) }\end{array}$ & Keeksklusivan & $\begin{array}{l}\text { Keunggulan atau kelebihan } \\
\text { masyarakat Tutem sebagai } \\
\text { bagian sonaf Mollo baik dari segi } \\
\text { kondisi alam, perekonomian, dan } \\
\text { alam sosialnya. }\end{array}$ \\
\hline 10 & $\begin{array}{l}\text { Kuning } \\
\text { Emas } \\
\text { (Golden) }\end{array}$ & Idem & $\begin{array}{l}\text { Jenis warna } \\
\text { alamiah dari } \\
\text { material emas }\end{array}$ & $\begin{array}{l}\text { Kekayaan dan } \\
\text { kejayaan }\end{array}$ & $\begin{array}{l}\text { Kekayaan hasil alam dan } \\
\text { kejayaan perekonomian hidup } \\
\text { masyarakat Tutem. }\end{array}$ \\
\hline
\end{tabular}

Tabel 2 Hasil Pemaknaan Etik Simbol Gambar Kain Tenun

\begin{tabular}{|c|c|c|c|c|c|c|}
\hline No & $\begin{array}{l}\text { Nama } \\
\text { Motif }\end{array}$ & $\begin{array}{l}\text { Gambar } \\
\text { Motif }\end{array}$ & Emik & Etik Objektif & $\begin{array}{l}\text { Etik } \\
\text { Subjektif }\end{array}$ & Rujukan Realitas \\
\hline 1 & $\begin{array}{l}\text { Gambar } \\
\text { Utama } \\
\text { Lulkolo }\end{array}$ & & $\begin{array}{l}\text { Realitas } \\
\text { historis } \\
\text { keberadaan } \\
\text { unggas } \\
\text { elang }\end{array}$ & $\begin{array}{l}\text { Bentuk ruang } \\
\text { yang terbentuk } \\
\text { oleh } 3 \text { sub-ruang } \\
\text { bujur sangkar } \\
\text { kecil yang } \\
\text { dihubungkan oleh } \\
\text { garis lurus beserta } \\
\text { garis lengkungan } \\
\text { dan hiasan berupa } \\
\text { renda-renda }\end{array}$ & $\begin{array}{l}\text { Sistem } \\
\text { sosial- } \\
\text { budaya }\end{array}$ & $\begin{array}{l}\text { Realitas } \\
\text { keberadaan } \\
\text { kefektoran } \\
\text { Paenenotobu } \\
\text { (Bijaipunu, Tutem, } \\
\text { Tobu) yang } \\
\text { senantiasa }\end{array}$ \\
\hline 2 & $\begin{array}{l}\text { Varian } \\
(01) \\
\text { Gambar } \\
\text { Lulkolo }\end{array}$ & & Idem & $\begin{array}{l}\text { Ruang bujur } \\
\text { sangkar yang } \\
\text { dibentuk oleh } 4 \\
\text { sub-ruang bujur } \\
\text { sangkar kecil } \\
\text { beserta garis } \\
\text { lengkungannya }\end{array}$ & $\begin{array}{l}\text { Ruang } \\
\text { lingkup } \\
\text { sosial- } \\
\text { budaya }\end{array}$ & $\begin{array}{l}\text { Realitas } \\
\text { ruang lingkup } \\
\text { sosial-budaya } \\
\text { masyarakat } \\
\text { Tutem yang } \\
\text { mencerminkan } \\
\text { keberadaan } 4 \text { suku } \\
\text { kaum Atoinamaf. }\end{array}$ \\
\hline 3 & $\begin{array}{l}\text { Varian } \\
(02) \\
\text { Gambar } \\
\text { Lulkolo }\end{array}$ & & Idem & $\begin{array}{l}\text { Ruang bujur } \\
\text { sangkar yang } \\
\text { terbentuk oleh } 5 \\
\text { sub-ruang bujur } \\
\text { sangkar kecil } \\
\text { berserta garis } \\
\text { lengkungannya }\end{array}$ & $\begin{array}{l}\text { Ruang } \\
\text { lingkup } \\
\text { sosial- } \\
\text { budaya }\end{array}$ & $\begin{array}{l}\text { Realitas } \\
\text { ruang lingkup } \\
\text { sosial-budaya } \\
\text { masyarakat } \\
\text { Tutem yang } \\
\text { mencerminkan } \\
\text { keberadaan } 4 \text { suku } \\
\text { kaum Atoinamaf. }\end{array}$ \\
\hline
\end{tabular}




\begin{tabular}{|c|c|c|c|c|c|c|}
\hline No & $\begin{array}{l}\text { Nama } \\
\text { Motif }\end{array}$ & $\begin{array}{l}\text { Gambar } \\
\text { Motif }\end{array}$ & Emik & Etik Objektif & Etik Subjektif & Rujukan Realitas \\
\hline 4 & $\begin{array}{l}\text { Varian } \\
(03) \\
\text { Gambar } \\
\text { Lulkolo }\end{array}$ & & Idem & $\begin{array}{l}\text { Ruang bujur } \\
\text { sangkar yang } \\
\text { diapati garis } \\
\text { lengkungan- } \\
\text { nya }\end{array}$ & $\begin{array}{l}\text { Ruang } \\
\text { lingkup } \\
\text { sosial-budaya }\end{array}$ & $\begin{array}{l}\text { Realitas ruang } \\
\text { lingkup sosial-budaya } \\
\text { kelompok masyarakat } \\
\text { Tutem yang senantiasa } \\
\text { mencerminkan } \\
\text { keberadaan } 4 \\
\text { kelompok suku kaum } \\
\text { Atoinamaf. }\end{array}$ \\
\hline 5 & $\begin{array}{l}\text { Varian } \\
(04) \\
\text { Gambar } \\
\text { Lulkolo }\end{array}$ & & Idem & $\begin{array}{l}\text { Persetuhan } 2 \\
\text { ruang bujur } \\
\text { sangkar yang } \\
\text { masing- } \\
\text { masingnya } \\
\text { diapiti garis } \\
\text { lengkungan }\end{array}$ & $\begin{array}{l}\text { Ruang } \\
\text { lingkup } \\
\text { sosial-budaya }\end{array}$ & $\begin{array}{l}\text { Realitas ruang } \\
\text { lingkup sosial-budaya } \\
\text { kelompok masyarakat } \\
\text { Tutem yang senantiasa } \\
\text { mencerminkan } \\
\text { keberadaan } 4 \\
\text { kelompok suku kaum } \\
\text { Atoinamaf. }\end{array}$ \\
\hline 6 & $\begin{array}{l}\text { Gambar } \\
\text { Mauninef } \\
\text { berupa } \\
\text { orang }\end{array}$ & & $\begin{array}{l}\text { Realitas } \\
\text { kehadiran } \\
\text { ragam } \\
\text { kelompok } \\
\text { suku }\end{array}$ & $\begin{array}{l}\text { Gambar } \\
\text { yang } \\
\text { terbentuk } \\
\text { dari bagian } \\
\text { kepala dan } \\
\text { badan }\end{array}$ & $\begin{array}{l}\text { Personal } \\
\text { manusia }\end{array}$ & $\begin{array}{l}\text { Realitas historis } \\
\text { keberadaan tokoh dan } \\
\text { bala tentara perang } \\
\text { masyarakat Tutem } \\
\text { yang menjaga dan } \\
\text { mempertahankan } \\
\text { wilayah kefektoran } \\
\text { Paenenotobu. }\end{array}$ \\
\hline 7 & $\begin{array}{l}\text { Gambar } \\
\text { Mauninef } \\
\text { berupa } \\
\text { burung }\end{array}$ & & $\begin{array}{l}\text { Realitas } \\
\text { historis } \\
\text { kehadiran } \\
\text { burung } \\
\text { elang }\end{array}$ & $\begin{array}{l}\text { Gambar } \\
\text { berbentuk } \\
\text { burung }\end{array}$ & $\begin{array}{l}\text { Keberanian } \\
\text { dan } \\
\text { ketangguhan }\end{array}$ & $\begin{array}{l}\text { Realitas keberanian } \\
\text { dan ketangguhan } \\
\text { tokoh dan bala tentara } \\
\text { perang kelompok } \\
\text { masyarakat Tutem. }\end{array}$ \\
\hline 8 & $\begin{array}{l}\text { Gambar } \\
\text { Lulkolo } \\
\text { kecil }\end{array}$ & & Idem & $\begin{array}{l}\text { Ruang bujur } \\
\text { sangkar } \\
\text { dengan } \\
\text { variasi garis } \\
\text { lengkungan } \\
\text { dan garis } \\
\text { lurus }\end{array}$ & $\begin{array}{l}\text { Status dan } \\
\text { peran sosial }\end{array}$ & $\begin{array}{l}\text { Realitas peranan } \\
\text { kelompok suku } \\
\text { kaum Atoinamaf } \\
\text { sebagai } 4 \text { kelompok } \\
\text { suku ujung tombak } \\
\text { dalam menjaga dan } \\
\text { mempertahankan } \\
\text { wilayah kefektoran } \\
\text { Paenenotobu. }\end{array}$ \\
\hline 9 & $\begin{array}{l}\text { Gambar } \\
\text { Abata }\end{array}$ & & $\begin{array}{l}\text { Realitas } \\
\text { kehadiran } \\
\text { ragam } \\
\text { kelompok } \\
\text { suku }\end{array}$ & $\begin{array}{l}\text { Kombinasi } \\
\text { ruang bujur } \\
\text { sangkar } \\
\text { membentuk } \\
\text { bangunan } \\
\text { tertentu }\end{array}$ & $\begin{array}{l}\text { Status dan } \\
\text { peranan sosial }\end{array}$ & $\begin{array}{l}\text { Realitas keberadaan } \\
\text { kelompok suku } \\
\text { Atoinamaf yang } \\
\text { senantiasa menjaga } \\
\text { dan mempertahankan } \\
\text { wilayah desa Tutem } \\
\text { secara khusus dan } \\
\text { wilayah kefektoran } \\
\text { Paenenotobu secara } \\
\text { umum. }\end{array}$ \\
\hline
\end{tabular}


Dalam tahapan kerja selanjutnya berupa dialog, maka peneliti harus mendiskusikan hasil pemaknaan etiknya dengan pihak masyarakat Tutem. Dialog ini dapat menghasilkan satu kesepakatan baik persetujuan atau penolakan bersama. Hasil kesepakatan menunjukkan bahwa semua hasil reinterpretasi peneliti atas makna simbolis warna kain tenun disetujui oleh masyarakat Tutem. Dalam pemaknaan emik mereka, ragam warna yang ada pada kain tenun mengekspresikan kehadiran berbagai kelompok suku yang tersebar lingkup sosia desa Tutem. Sedangkan pemaknaan etik peneliti mengkonstruksi makna simbolis dari tiap warna kain tenun secara lebih kaya. Persetujuan mereka didasarkan pada dalil minimnya makna simbolis warna pada kain tenunnya.

Terdapat 9 jenis gambar kain tenun yang disetujui reinterpretasi pemaknaan simbolisnya oleh masyarakat Tutem. Beberapa gambar tersebut, yaitu: 1 varian gambar Ausnobif, 4 varian gambar Lulkolo, 2 varian gambar Mauninef, dan 1 gambar Abata. Bagi masyarakat Tutem, ke-7 gambar tersebut dikategorikan sebagai varian gambar pendamping yang turut mempercantik tampilan visual gambar-gambar utama pada kain tenun. Sehingga pemaknaan simbolis 7 varian gambar pendamping ini dapat bersifat lentur dalam pemaknaan dengan satu syarat, yaitu: acuan pemaknaan simbolisnya tidak boleh melampaui lingkup sosial-budaya masyarakat Tutem. Sedangkan gambar utama Ausnobif dan Lulkolo relatif tetap dipertahankan pemaknaan simbolis emiknya. Kedua gambar utama ini punya kedudukan khusus bagi masyarakat Tutem. Identitas masyarakat Tutem sebagai sebuah kelompok budaya khas ditandai oleh kehadiran gambar utama Ausnobif dan Lulkolo.

Bukan soal kehadiran gambar dengan bentuk tertentu, tetapi nilai di balik gambar tersebut. Kedua gambar utama ini ada sebagai tanda bahwa kelangsungan hidup mereka dimulai dan dijamin oleh peran 2 jenis fauna, yaitu: anjing dan elang. Peneliti sendiri memiliki 2 tujuan dalam melakukan pembacaan dekonstruksi, yaitu: 1) Peneliti tidak mau terjebak dalam mitos simbol dan karenanya, peneliti bersikap afirmatif terhadap pengakomodiran kemajemukan berbagai bentuk signifikasi dan 2) Peneliti bermaksud menghadirkan realitas rujukan bernuansa lain yang ditandai oleh simbol warna dan gambar kain tenun. Terdapat 3 simbol warna dan pola gambar beruang pada kain tenun masyarakat Tutem, akan didekonstruksi guna menunjukkan fleksibilitas maknanya.

Warna merah tidak hanya dimaknai sebagai ekspresi keberanian. Warna merah merupakan warna darah manusia atau hewan. Darah menjadi salah satu dimensi dalam ritus korbani, yaitu purifikasi (Sindhunata, 2006: 108). Masyarakat Tutem juga menghidupi ritus korbani dengan pembunuhan dan pengorbanan darah hewan. Pembunuhan hewan menjadi tanda kekerasan terhadap satu bentuk kehidupan. Sehingga warna merah juga menandai kekerasan dalam habitus budaya lokal masyarakat Tutem.

Warna hijau tidak melulu menandai kesuburan alam dan kekayaan SDA yang dikecapi oleh masyarakat Tutem. Kesenjangan ekonomi dalam hal kepemilikan modal tanah (lahan) yang tidak merata, menjadi soal bagi masyarakat Tutem karena dapat mengakibatkan kecemburuan sosial dan konflik. Sehingga tidak menutup kemungkinan warna hijau juga ekspresi benturan sosial. Eksklusivitas kelompok masyarakat Tutem yang ditandai warna ungu, dapat menimbulkan kekerasan. Masyarakat Tutem memang perlu menandai diri mereka guna membedakan dirinya dari kelompok masyarakat lainnya. Penghayatan dan sikap yang berlebihan terhadap penandaan identitas demikian, dapat bermuara pada etnosentrisme dan diskriminasi. Sehingga ekslusivitas warna hijau justru dapat menandai dimensi jurang (gap) sosial yang dikonstruk oleh masyarakat Tutem sendiri.

Pola gambar beruang terbentuk atas garis pemisah antar sisi. Demikian pun, ketika garisgaris ini akhirnya membangun pola ruangruang tertentu. Baik garis atau ruang berfungsi sebagai pemisah. Identitas masyarakat Tutem tidak selamanya bermakna tunggal, yaitu menandai kekhasan. Identitas juga dapat menjadi garis pemisah yang beroperasi secara ekstrem dalam satu konteks kehidupan sosial, yaitu etnosentrisme dan dominasi. Pemahaman ini menandai acuan lain yang ditandai oleh fungsi garis dan ruang.

Pakaian (fashion) berfungsi mengikat satu komunitas atau kelompok sosial-budaya tertentu. Kain tenun adalah salah satu varian busana yang dikenakan oleh manusia. Sehingga kain tenun menjalankan fungsi pengikat kelompok budaya pemiliknya. Untuk 
menjalankan fungsi ini, maka kain tenun hadir sebagai sebuah identitas budaya. Kain tenun membedakan identitas budaya kelompok pemiliknya dari kelompok lainnya. Dalam hal ini, satuan pembeda kain tenun masyarakat Tutem nampak pada corak tampilan visual beserta pemaknaan simbolisnya. Oleh karena itu, kualitas dan karakteristik kelompok budaya tertentu adalah identitas budayanya.

Ketika masyarakat Tutem memproduksi dan berbusana kain tenun dengan corak visual warna dan gambar tertentu, maka hal ini sesungguhnya beroperasi pada proses pengiriman pesan. Praktik berbusana demikian kadang tidak disadari, tetapi punya konsekuensi dimaknai oleh orang lain dengan efek pemaknaannya, yaitu: pengidentifikasian sebagai identitas budaya (Barnad, 1996: iv). Identitas masyarakat Tutem yang ditandai oleh praktik penandaan kain tenunnya berbeda dari identitasnya di masa silam dan akan menjadi tak sama pula untuk masa mendatang. Tempus mutantur, et nos mutamur in illid. Waktu berubah dan praktik penandaan budaya kain tenun akan mengubah identitas masyarakat Tutem.

Baik masyarakat Tutem dan peneliti sebenarnya sama-sama terlibat dalam pemaknaan konotasi simbol warna dan gambar kain tenun. Makna denotasinya bagi kedua interpreter ini adalah tampilan visual dengan kualitas dan karakteristik tertentu. Sebaliknya, makna konotasi yang diperoleh ditentukan oleh kondisi atau pengalaman interpreter. Makna konotasi simbol warna dan gambar kain tenun bagi masyarakat Tutem didasarkan pada sistem pengetahuan bersama (konsesus) dan peneliti mereproduksi makna konotasi berdasarkan pengetahuannya (keilmuan).

Pemaknaan etik peneliti sesungguhnya menandai pemaknaan tanda konotasi kedua di atas konotasi pertama. Ini sengaja dimaksudkan peneliti guna mengantisipasi proses naturalisasi, yaitu: proses menghubungkan penanda dan petanda secara beku dan baku. Proses ini berujung pada pembentuk mitos signifikasi tanda. Relasi penanda dan petanda akhirnya berkualitas historis dan natural. Sistem mitos memiliki kecenderungan untuk menaturalisasikan hubungan kausal yang sebenarnya hanya artifisial (Sunardi, 2004: 98).

Terlalu dini untuk membakukan pemaknaan simbol warna dan kain tenun masyarakat Tutem sebagai yang bersifat final dan tunggal. Hal ini dikarenakan 2 hal, yaitu: 1) proses signifikasi simbol warna dan kain tenun secara kaku hanya akan medehumanisasi kesadaran masyarakat Tutem selaku pemiliknya dan 2) realitas yang diacu penanda warna dan gambar kain tenun selalu bersifat dinamis. Kedua argumentasi ini menjadi keyakinan yang mendorong peneliti untuk mendenaturalisasikan signifikasi emik tanda konotasi warna dan gambar kain tenun.

Selaku mitos, signifikasi tanda demikian harus didenaturalisasikan. Artinya, dalam proses signifikasi tanda, manusia harus terbebaskan dari beban pra-anggapan naturalitas singfikasi tanda. Dalam asumsi semiotika kritis, penanda dan petanda tidak terlibat dalam hubungan permanen, tetapi keduanya selalu berdialetika sehingga menghasilkan berbagai signifikasi baru. Kesadaran untuk mengantisipasi kemajemukan makna di kemudian hari harus menjadi sikap bijak individu manusia ketika berperan sebagai pelaku-pelaku simbol bahasa. Konsep konotasi, mitos, atau the death of author oleh Barthes adalah berbagai penjelasan rasional yang menyiapkan jalan bagi sebuah pembacaan yang dapat melampui tradisi pemaknaan teks sebelumnya.

Pembacaan teks (sosial atau budaya) secara kritis oleh Barthes dapat digolongkan ke dalam upaya memposisikan kegunaan ilmu pengetahuan secara bijak bagi kehidupan manusia. Reinterpretasi simbol warna dan gambar kain tenun adalah wujud tanggung jawab ilmu pengetahuan (diwakili peneliti) untuk bisa mendatangkan sesuatu yang berguna bagi masyarakat Tutem sendiri.Peran simbol warna dan gambar memberi kontribusi pada efektivitas dan keberhasilan komunikasi antar kebudayaan (Permana, 2015: 9). Asumsinya makna simbolis warna dan gambar kain tenun memiliki potensi untuk dapat diperkaya.

Dalam filsafat ilmu, tiap ilmu pengetahuan yang diproduksi manusia ditujukan bagi kesejahteraan hidup manusia sendiri. Akan tetapi, Habermas memperingati teori-teori kritis bahwa suatu perubahan emansipatif hanya dimungkinkan jika turut melibatkan pendekatan komunikasi melalui media-media rasional dan efektif. Poin Habermas adalah teori-teori kritis yang memperjuangkan emansipasi dalam kehidupan manusia justru dapat menjadi tidak emansipatif jika tidak mempertimbangkan subjek manusia yang hendak dibebaskan dari entitas kekuasaan (ideologi) tertentu (Sutrisno 
dan Putranto, 2009: 43).

Peneliti memang mengharapkan hasil reinterpretasinya dapat menjadi pengetahuan sosial bagi masyarakat Tutem. Tetapi hal demikian tidak serta-merta dipaksakan kepada masyarakat Tutem, tetapi harus melalui tahap konfirmasi, dialog, persetujuan, dankesepakatan. Dialog merupakan jalan memperlakukan masyarakat Tutem secara manusiawi sekaligus menghindari logosentrisme pemaknaan simbol warna dan kain tenun oleh peneliti. Dengan demikian, optimalisasi makna simbolis warna dan gambar kain tenun menjadi jalan yang dipilih oleh peneliti untuk bisa mengfungsikan ilmu pengetahuan bagi kehidupan manusia yang berciri emansipatoris (kungkungan tradisi pemaknaan) sekaligus bernilai guna praktis bagi kesejahteraan hidup masyarakat Tutem.

Secara historis, pemaknaan emik simbol warna dan gambar kain tenun diproduksi oleh pengarangnya, yaitu masyarakat Tutem. Melalui analisis Barthes, peneliti menunjukkan posibilitas kehadiran petanda bagi penanda warna dan gambar kain tenun. Sedangkan ketidakstabilan petanda dibuktikan peneliti melalui pembacaan dekonstruksi Derrida. Tujuan keduanya satu, yaitu: kematian pengarang. Kematian pengarang adalah harga yang harus dibayar untuk melahirkan pembaca. Jadi kematian pengarang dan kelahiran pembaca adalah 2 kutub peristiwa tekstual tak terpisahkan. Namun, peristiwa tekstual ini harus dipahami secara kritis. Barthes dan Derrida (serta Michel Foucault) sependapat soal kematian Author tidak serta-merta menghilangkan eksistensinya. Kematian pengarang lebih dimaksudkan pada ketiadaan otoritas kepengarangan (Authority) dalam menetapkan makna karyanya. Kekosongan otoritas tersebut akan segera diisi oleh peran pembaca sehingga sebuah karya bertransformasi menjadi teks (Sunardi, 2004: 242-243).

Ketika corak visual warna dan gambar kain tenun menjadi teks, maka hal itu menandai pelepasan otoritas pemaknaan emik oleh masyarakat Tutem dan siap dimaknai secara etik oleh peneliti. Meskipun berstatus teks, kehadiran masyarakat disisakan oleh jejak-jejak eksistensi warna dan gambar kain tenun sebagai produk kebudayaannya. Oleh Foucault, peran ini disebut distribusi wacana. Tanpa sebuah wacana kehadiran tanda warna dan gambar kain tenun, mustahil peneliti bisa melakukan reinterpretasi dan dekonstruksi.

\section{SIMPULAN}

Proses dialektika antara etnografi emik dan etnografi etik dalam penelitian ini disusun ke dalam 4 tahapan kerja, yaitu: interpretasi, reinterpretasi, dialog, dan dekonstruksi. Pada tahap interpretasi, peneliti mencoba menghadirkan pemaknaan native (emik) dari masyarakat Tutem terhadap simbol warna dan gambar kain tenunnya. Proses pemaknaan tersebut dilakukan dengan mengidentifikasi aspek penanda dan petandanya, serta mengoperasionalisasikan hubungan di antara keduanya (signifikasi).

Dalam proses interpretasi, warna dan gambar kain tenun diposisikan sebagai aspek penanda yang mengacu maknanya pada realitas kebudayaan masyarakat Tutem, selaku petandanya. Hasilnya, terdapat 10 jenis warna yang ada pada kain tenun masyarakat Tutem hanya memiliki satu bentuk pemaknaan saja, yaitu realitas kehadiran sub kelompok suku yang berada dalam kehidupan sosial masyarakat Tutem. Sebaliknya, dari 11 ragam gambar kain tenun yang teridentifikasi, 1 gambar utama Ausnobif dan 1 variannya memiliki bentuk acuan makna yang sama, 1 gambar utama Lulkolo dan 4 variannya mengacu pada makna yang sama, dan 4 gambar kecil lainnya masing-masing memiliki makna acuannya yang berbeda-beda.

Bagi peneliti, pemaknaan emik demikian masih bisa dioptimalisasi ragam bentuk pemaknaannya untuk menjadi lebih kaya. Oleh karena itu, peneliti melakukan proses reinterpretasi yang menandai bentuk pemaknaan dari peneliti (etik). Hasilnya, tiap 10 jenis warna kain tenun masyarakat Tutem memiliki bentuk pemaknaan masing-masingnya. Pada dimensi gambar, terdapat 1 gambar utama Ausnobif dan pemaknaan etiknya, 1 varian gambar Ausnobif dan pemaknaan etiknya, 1 gambar utama Lulkolo dan pemaknaan etiknya, 4 varian gambar Lulkolo dan pemaknaan etiknya yang sama, serta 4 gambar kecil dengan bentuk pemaknaan etik masing-masingnya.

Pada tahapan selanjutnya dalam penelitian ini, peneliti menyelenggarakan proses dialog antara masyarakat Tutem dan peneliti. Dari pihak masyarakat Tutem, terkhususnya diwakili oleh kelompok tokoh masyarakat/adatnya 
(opinion leader). Proses komunikasi timbalbalik ini dimaksudkan agar hasil pemaknaan etik peneliti bisa disetujui oleh masyarakat Tutem dan menjadi pengetahuan budaya mereka. Hasil dialog tersebut menyepakati pemaknaan etik atas 10 jenis gambar dan 9 ragam gambar diterima dan 2 bentuk gambar utama ditolak. Dialog dan kesepakatan intersubjektif yang dicapai dalam penelitian ini, sesungguhnya menandai peran emansipatif ilmu pengetahuan dalam memberdayakan entitas kehidupan sosial-budaya masyarakat Tutem.

Akhirnya, penelitian ini dapat menjadi satu di antara sekian rujukan penelitian yang mengapresiasi spirit komunikatif-emansipatoris dalam pelaksanaannya. Akhirnya, fungsi praktis kain tenun tidak sebatas busana atau penanda identitas budaya bagi masyarakat Tutem. Penting bagi mereka untuk terus meregenerasi eksistensi kain tenun sebagai sebuah tradisi. Namun, aktivitas budaya demikian tidak cukup menyentuh maksud kehadiran kain tenun. Makna simbolis kain tenun merupakan hasil konstruksi sosial dan budaya secara berkesadaran. Di balik corak visual kain tenun bersemayam nilai-nilai historis dan ideal kehidupan sosial dan budaya tertentu. Nilai ini ada untuk diwujudkan dalam sikap dan perilaku masyarakat Tutem sendiri. Nilai ini harus menjadi epistemologi bersama di antara masyarakat Tutem untuk terus dilestarikan melalui praktik hidup.

\section{DAFTAR PUSTAKA}

Al-Fayyadl, M. (2006). Derrida. Yogyakarta: Lkis

Barnard, M. (2007). Fashion sebagai komunikasi: cara mengkomunikasikan identitas sosial, seksual, kelas, dan gender. Yogyakarta: Jalasutra

Budiman, K. (2004). Jejaring tanda: strukturalisme dan semiotik dalam kritik kebudayaan. Magelang: Penerbit Indonesia Tera

Hardiman, F, B. (2004). Filsafat moderen: dari machiavelli sampai nietzsche. Jakarta: Gramedia Pustaka Utama

Hardiman, F, B. (2009). Demokrasi deliberatif. Yogyakarta: Penerbit Kanisius
Kruger, S. (2008). Ethnography in the performing arts: a student guide. London: The Higher Education Academy

Kuswarno, E. (2008). Metode penelitian komunikasi: etnografi komunikasi: suatu pengantar dan contoh penelitiannya. Bandung: Widya Padjadjaran

Liliweri, A. (2002). Makna budaya dalam komunikasi antarbudaya. Yogyakarta: LkiS

Liliweri, A. (2009). Dasar-dasar komunikasi antarbudaya. Yogyakarta: Pustaka Pelajar

Mulyana, D. \& Rakhmat, J. (2010). Komunikasi antarbudaya: panduan berkomunikasi dengan orang-orang berbeda budaya. Bandung: Remaja Rosdakarya

Mulyana, D. \& Solatun. (2007). Metode penelitian komunikasi: contoh-contoh penelitian kualitatif dengan pendekatan praktis. Bandung: Remaja Rosdakarya

Pawito. (2007). Penelitian komunikasi kualitatif. Yogyakarta: LkiS

Permana, R, S, M.( 2015). Makna tri tangtu di buana yang mengandung aspek komunikasi politik dalam fragmen carita parahyangan. Jurnal Kajian Komunikasi. Vol. 3/2. Diakses dari http://journal.unpad.ac.id/jkk/ article/view/7407/3409

Peursen, C, A, V. (2005). Strategi kebudayaan. penerjemah dick hartoko. Yogyakarta: Penerbit Kanisius

Sindhunata. (2006). Dilema usaha manusia rasional: kritik masyarakat moderen oleh max horkheimer dalam rangka sekolah frankfurt. Jakarta: Gramedia

Sobur, A. (2009). Semiotika komunikasi. Bandung: Remaja Rosdakarya

Sunardi, St. (2004). Semiotika negativa. Yogyakarta: Penerbit Buku Baik

Sutrisno, M. \& Hendar, P. (2009). Teori-teori kebudayaan. Yogyakarta: Penerbit Kanisius

Suseno, F, M. (2005). Pijar-pijar filsafat: dari gatholoco ke filsafat perempuan, dari adam muller ke postmoderenisme. Yogyakarta: Penerbit Kanisius

West, R \& Lynn, H, T. (2008). Pengantar teori komunikasi: analisis dan aplikasi. Penerjemah Maria Natalia Damayanti Maer. Jakarta: Penerbit Salemba Humanika 